Vol. XIV, No. 3

\title{
Priestley Island
}

Priestly Island, near the south end of Reindeer Lake, has been named, effective July 5 th, 1956 , by the Canadian Board of Geographical Names at Ottawa to commemorate the outstanding work of the late Mrs. Isabel M. Priestly in creating interest in Saskatchewan natural history. When the Saskatchewan Natural History Society was invited to nominate an outstanding Saskatchewan naturalist to be honoured in this way, the executive chose the name of Mrs. Priestly because the Blue Jay magazine, the Yorkton Natural History Society, and the Saskatchewan Natural History Society all owe their existence to her.

The first issue of the Blue Jay was published in 1942 when Mrs. Priestly took the lead in organizing the Yorkton Natural History Society. It was Mrs. Priestly who compiled the material for the Blue Jay and did much of the actual work involved in mimeographing the bulletin. In addition, she wrote hundreds of letters and answered innumerable inquiries about natural history.

When Mrs. Priestly died in 1946, the Yorkton Natural History Society continued the Blue Jay as a memorial to her. Then a provincial society was formed to publish the magazine. Thus Mrs. Priestly's inspiration can be considered responsible for the organization of the Saskatchewan Natural History Society wh i c h brought naturalists together in a manner that had always been the cherished dream of the first editor.

All our members will feel that Mrs. Priestly's service to the cause of natural history in the province justifies perpetuating her name as a Saskatchewan place name. Not only was she responsible for organizing the Yorkton Natural History Society, which is still active, and for beginning the publication of the Blue Jay which now has a circulation of over two thousand; she stimulated by her keen personal enthusiasm a wide interest in the study of natural history during the years of her residence in Saskatchewan.

\section{The Blue Jay Bookshelf "PLANTING YOUR GARDEN FOR WILD BIRDS" \\ By James R. Mackintosh}

Audubon Society of Canada, 1956- $\$ 1.00$ - Reviewed by Mary Houston, Yorkton

In this little book, written for the Audubon Society of Canada, James R. Mackintosh attempts to give practical guidance to anyone wishing to derive more pleasure both from his garden and from the wild birds it might attract. Sketches by such artists as Roger Tory Peterson and T. M. Shortt add to the booklet's attractiveness.

Since the essentials for sustaining birdlife (particularly in winter) include food, water, and shelter, the author suggests that much more can be done than simply putting out food trays - though these are valuable. Different shrubs and trees will attract a larger variety of birds and thus add to the birdwatcher's pleasure and knowledge while they increase the comfort of the birds.

Mr. Mackintosh has prepared a detailed chart of trees, shrubs, and other plants in which he describes each and explains its specific value to the birds as food, shelter, or nesting habitat. Because the guide is intended for all Canada, the author also gives zones in which each plant will grow and tells which birds are attracted to it. He suggests plans for small, large, and wild gardens to give the reader ideas on how to make the garden attractive to himself and to the birds. Where feeding stations are set up, they supplement natural food.

Mr. Mackintosh has been superintendent of Glendon Hall-over 100 acres in the heart of Toronto, now the property of the University of Toronto's Department of Biologyfor over twenty years. $\mathrm{He}$ is also a keen naturalist and a professional horticulturist, so he is well qualified to guide the interested amateur to hours of greater pleasure in "Planting Your Garden for Wild Birds." 